Ярошевич Ирина Наумовна, доцент, Ангарский государственный технический университет, e-mail: irina.yaroschevitch @ yandex.ru

САМОКОНТРОЛЬ ФУНКЦИОНАЛЬНОГО СОСТОЯНИЯ ОРГАНОВ ДЫХАНИЯ СТУДЕНТОВ АНГТУ

Yaroshevich I.N.

\title{
SELF-CONTROL OF FUNCTIONAL STATE OF RESPIRATORY SYSTEM STUDENTS ASTU
}

\author{
Аннотация. Рассмотрена проблема самоконтроля состояния органов дыхания при фри- \\ зической нагрузке. \\ Ключевые слова: физическая подготовленность, студенты, функциональное состоя- \\ ние, органы дыхания, частота дыхания, ритм дыхания. \\ Annotation. The problem of self-control of the respiratory system during exercise is consid- \\ ered.
}

Key words: Physical fitness, students, functional state, respiratory organs, respiratory rate, breathing rhythm.

Для хорошей фризической подготовленности студентов очень важно заниматься на учебных занятиях самоконтролем функционального состояния органов дыхания, которое можно оценить по частоте дыхания, жизненной емкости легких пробами Генчи и Штанге, связанных с задержкой дыхания. В состоянии мышечного покоя дыхание должно быть ритмичным, спокойным. Были проанализированы 19 студенток - девушек второго курса АнГТУ, у которых частота дыхания находилась в пределах 12-18 дыхательных движений в минуту (вдох и выдох составляет одно движение). Девушки, занимаясь в тренажерном зале на силовые качества, делали замеры. Во время нагрузки дыхание составляло 2438 дыхательных движений, при максимальных нагрузках дыхание участилось до 40-48 с быстрым возвращением к исходному уровню. Девушки подсчитывали дыхание в течение 1 мин, положив руки на нижнюю часть груди. Из 19 испытуемых девушек, у 3-х появилось резкое учащения дыхания, что свидетельствует о появлении одышки, которая сопровождается чувством недостатка воздуха, стеснением в груди, кашлем во время нагрузки или после нее. Это указывает на несоответствие фризической нагрузки возможностям организма (чаще бывает при слабой физической подготовленности). Дыхание во время фризической нагрузки должно соответствовать ритму движения [1].

Факторы, определяющие интенсивность фризической нагрузки на учебных занятиях по физической культуре, позволили создать учебную программу занятий средней степени интенсивности, не приводящие студенток - девушек к переутомлению. Для выполнения этой программы исследования проводилась проба Генчи - регистрация времени задержки дыхания в минуту. Девушки задерживали дыхание после максимального выдоха. В начале исследования де- 
лали глубокий вдох, затем максимальный выдох. При этом задерживали дыхание, зажав нос и рот. Регистрировали время задержки дыхания между вдохом и выдохом. Результат показал у 10-ти девушек 21 дыхательное движение, остальные показали результат хуже - 16 дыхательных движений. В норме величина пробы Генчи составляет 20-40 секунд. Исследовали пробу Штанге, которая регистрировалась временем задержки дыхания при глубоком вдохе. В начале девушки делали вдох, выдох, а затем вдох на уровне $80 \%$ от максимального. Закрывали рот, зажимали нос. После выдоха регистрировали время задержки. Средний результат показали 9 девушек - 36 дыхательных движений, остальные показали результат - 22 дыхательных движения.

Была зафиксирована проба Штанге с физической нагрузкой в покое: выполнялось 20 приседаний за 30 секунд. После окончания фризической нагрузки сразу же проводилась повторная проба Штанге. Время повторной пробы сокращалось в 2 раза. По величине показателя пробы Генчи можно косвенно судить об уровне обменных процессов, степени адаптации дыхательного центра к гипоксии [1].

Таким образом, самоконтроль функционального состояния органов дыхания студенток - девушек оценивался в ходе изучения функционального состояния организма в целом. Учебной программой ВУЗа предъявляются высокие требования к реализации учебного процесса по физической культуре. Для их выполнения необходимо осуществлять самоконтроль органов дыхания, который обеспечивает эффрективную работу всей кардиореспираторной системы. Самоконтроль исследования органов дыхания проводился по общепринятым пробам Генче и Штанге при осуществлении физических нагрузок. Исследования показали удовлетворительное функциональноое состояние органов дыхания девушек.

\section{ЛИТЕРАТУРА}

1. Макарова Г.А. Спортивная медицина. - М.: Советский спорт, 2002. $478 \mathrm{c}$.

2. Ярошевич И.Н. Легкая атлетика в учебно-тренировочном процессе для студентов технических вузов: учебное пособие. - Ангарск: АГТА, 2011. - 84 с. 